\title{
PII S0016-7037(99)00355-5
}

\section{Rutile/melt partition coefficients for trace elements and an assessment of the influence of rutile on the trace element characteristics of subduction zone magmas}

\author{
Stephen F. Foley, ${ }^{1, *}$ Matthias G. Barth, ${ }^{2}$ and George A. Jenner ${ }^{3}$ \\ ${ }^{1}$ Mineralogisch-Petrologisches Institut, Universität Göttingen, Goldschmidtstrasse 1, 37077 Göttingen, Germany \\ ${ }^{2}$ Department of Earth and Planetary Sciences, Harvard University, 20 Oxford Street, Cambridge, Massachusetts 02138, USA \\ ${ }^{3}$ Department of Earth Sciences, Memorial University of Newfoundland, St. John's, Newfoundland AIB 3X5, Canada
}

(Received February 24, 1999; accepted in revised form August 17, 1999)

\begin{abstract}
Fractionation of some or all of the high field strength elements (HFSE) $\mathrm{Nb}, \mathrm{Ta}, \mathrm{Zr}$, Hf, and Ti relative to other trace elements occurs in igneous rocks from convergent margins and in the average continental crust, and is generally attributed to a process occurring during subduction. The experimental partitioning of an extensive array of trace elements between rutile/melt pairs is presented which enables the effect of rutile during melting in subduction zones to be directly assessed. $D_{\mathrm{Nb}}$ and $D_{\mathrm{Ta}}$ are in the range $100-500, D_{\mathrm{Zr}}$ and $D_{\mathrm{Hf}}$ are about 5 , whereas all other trace elements analyzed have $D^{\text {rutile/melt }}$ less than 0.1 . Published $D$ patterns for $\mathrm{Nb}$ and Ta between rutile and water-rich fluids are similar to those for melt, whereas the values for $\mathrm{Zr}$ and $\mathrm{Hf}$ are significantly higher. $D_{\mathrm{Nb}}$ and $D_{\mathrm{Ta}}$ values for clinopyroxene and garnet are much lower than for rutile, and cannot cause the fractionation of HFSE from other elements seen in island arcs. The presence of rutile in the subducted slab residue during dehydration may be essential in the production of the geochemical signatures of arc magmas, whereas that of the continental crust, including higher $\mathrm{Zr} / \mathrm{Sm}$, may be produced by melting of eclogite. Copyright (C) 1999 Elsevier Science Ltd
\end{abstract}

\section{INTRODUCTION}

The trace element signatures of island arc magmas and the continental crust deviate from those of oceanic basalts, showing that one or more processes in addition to melting of peridotite must contribute to their generation. Island arc magmatic rocks exhibit characteristically low abundances for the high field strength elements $\mathrm{Nb}, \mathrm{Ta}, \mathrm{Zr}, \mathrm{Hf}$, and $\mathrm{Ti}$ relative to those of other incompatible elements, resulting in characteristic negative anomalies in normalized incompatible element variation patterns, in particular for $\mathrm{Nb}$ and $\mathrm{Ta}$. The mechanism for this is debated, although it almost certainly takes place in or above the subducted slab. Many studies of the origin of the continental crust conclude that it also formed in association with subduction zones because of the overall similarity in composition between andesites and the continental crust (Taylor and McLennan, 1985). The continental crust also shows negative anomalies for $\mathrm{Nb}$, $\mathrm{Ta}$, and $\mathrm{Ti}$, but it differs from many island arc lavas in having no relative depletion of $\mathrm{Zr}$ and $\mathrm{Hf}$ (Rudnick and Fountain, 1995), and may for upper continental crust have positive anomalies relative to $\mathrm{Sm}$. These differences must be accounted for in the genetic mechanisms proposed. Although the growth curves of the continental crust are debated, much of the continental crust appears to have formed in Archean and early Proterozoic times (McLennan and Taylor, 1982; Nelson and DePaolo, 1985) when the processes involved may have been different due to higher geothermal gradients at that time. A better understanding of the underlying mechanisms for the fractionation of HFSE in subduction zones is also important for the assessment of the role of recycled subducted material in oceanic magmatic rocks.

* Author to whom correspondence should be addressed Dr. S. Foley, Universität Göttingen, Mineralogisch-Petrologisches Inst., Goldschmidstrasse 1, 37077 Göttingen, Germany.
Most authors favor one of two hypotheses for the origin of the HFSE anomalies. In the first, partial melting of either the subducted slab or of the mantle wedge overlying it can cause the anomalies due to the stability of rutile or another titanate mineral which retains the HFSE. It is now established on the grounds of experimental solubility measurements of rutile (Green and Pearson, 1986; Ryerson and Watson, 1987) and also from geochemical studies of island arc volcanics (Woodhead et al., 1993; Thirlwall et al., 1994), that rutile cannot coexist with basaltic melts arising from partial melting of peridotite in the mantle wedge. It may, however, be present during melting of the subducting oceanic crust (Ringwood, 1990) or of non-peridotitic parts of the mantle wedge (Foley and Wheller, 1990). The second hypothesis appeals to fluid loss by dehydration reactions in the subducting plate: this is consistent with thermal models for subduction zones which suggest that the melting points of subducted materials are not usually attained at relevant depths (Peacock, 1996; Poli and Schmidt, 1995). In this scenario, the HFSE anomalies in the volcanic melt compositions are obtained from melting of a mantle wedge which itself is depleted in the HFSE due to preferential enrichment of all other incompatible elements by the slabderived fluid. Recent experimental work contains evidence both for (Keppler, 1996) and against (Brenan et al., 1995; Stalder et al., 1998) the existence of HFSE anomalies in fluids without the need for residual titanate minerals. There has been a tendency to associate the necessity of residual titanate minerals with melting processes, although it applies equally to dehydration reactions.

The full understanding and quantification of the development of HFSE anomalies in subduction zone magmatism has been hampered by the lack of partitioning data for large trace element sets between rutile and melt, for which we here present new data. The application of laser ablation microprobe- 
Table 1. Rutile/melt partitioning in experiments on Lalkaldarno tonalite.

\begin{tabular}{|c|c|c|c|c|c|c|c|c|c|c|}
\hline \multirow[b]{3}{*}{ Expt. } & \multirow{3}{*}{$\frac{18 / 900^{\mathrm{b}}}{\text { Rutile }}$} & \multicolumn{2}{|l|}{69} & \multicolumn{3}{|c|}{71} & \multicolumn{3}{|c|}{42} & \multirow{3}{*}{$\begin{array}{c}\text { Undoped } \\
\text { tonalite }\end{array}$} \\
\hline & & \multicolumn{2}{|c|}{ (IW) Doping mix 2} & \multirow{2}{*}{$\frac{25 / 1100^{\mathrm{b}}}{\text { Rutile }}$} & \multicolumn{2}{|c|}{ Doping mix 1} & \multirow{2}{*}{$\frac{18 / 1025^{\mathrm{b}}}{\text { Rutile }}$} & \multicolumn{2}{|c|}{ Doping mix 2} & \\
\hline & & Glass & $D_{\mathrm{Ru} / \mathrm{L}}$ & & Glass & $D_{\mathrm{Ru} / \mathrm{L}}$ & & Glass & $D_{\mathrm{Ru} / \mathrm{L}}$ & \\
\hline $\mathrm{Rb}$ & $<43.9$ & 2368 & $<0.019$ & & 24.7 & & 12.9 & 1692 & 0.0076 & $12^{\mathrm{c}}$ \\
\hline $\mathrm{Sr}$ & $<22.7$ & 469 & $<0.048$ & 14.8 & 400 & 0.06 & 12.5 & 347 & 0.036 & $438^{\mathrm{c}}$ \\
\hline Y & $<10.5$ & 22.8 & $<0.459$ & 12.9 & 1760 & 0.007 & $<1.76$ & 23.1 & $<0.076$ & $8^{\mathrm{d}}$ \\
\hline $\mathrm{Zr}$ & 260 & 68.6 & 3.79 & 309 & 72.8 & 4.24 & 186 & 61 & $\mathbf{3 . 0 7}$ & $80^{c}$ \\
\hline $\mathrm{Nb}$ & 36,202 & 67 & 540 & 377 & 3.7 & 102 & 20,562 & 151 & 136 & $3^{\mathrm{d}}$ \\
\hline $\mathrm{Ba}$ & $<4.78$ & 243 & $<0.020$ & 8.2 & 1912 & 0.0043 & 1.16 & 85 & 0.0137 & $112^{\mathrm{c}}$ \\
\hline $\mathrm{La}$ & $<6.12$ & 25.8 & $<0.237$ & 8.02 & 1463 & 0.0055 & & 19.1 & & $7.8^{\mathrm{c}}$ \\
\hline $\mathrm{Ce}$ & $<4.52$ & 15.3 & $<0.296$ & $<1.86$ & 12.2 & & $<1.06$ & 12.2 & $<0.087$ & $15.1^{\mathrm{b}}$ \\
\hline $\mathrm{Nd}$ & $<17.6$ & 25.6 & $<0.684$ & $<12.4$ & 1457 & $<0.0085$ & $<5.5$ & 19.8 & $<0.277$ & $9.03^{\mathrm{c}}$ \\
\hline $\mathrm{Sm}$ & $<41.9$ & 17.5 & $<2.4$ & $<28.4$ & 1730 & $<0.0164$ & & 17.2 & & $2.1^{\mathrm{c}}$ \\
\hline $\mathrm{Eu}$ & $<9.6$ & 2177 & $<0.0044$ & $<7.4$ & 13.7 & & 0.6 & 1607 & 0.00037 & $0.679^{c}$ \\
\hline $\mathrm{Gd}$ & $<31.0$ & 1728 & $<0.018$ & $<21.5$ & 13.7 & & $<5.6$ & 1516 & $<0.0037$ & $2.2^{\mathrm{c}}$ \\
\hline Dy & & & & 17.1 & 1701 & 0.0101 & $<0.013$ & 17.1 & $<0.00076$ & $2.02^{\mathrm{c}}$ \\
\hline Но & & & & & & & & 0.31 & & $0.41^{\mathrm{c}}$ \\
\hline $\mathrm{Er}$ & $<10.9$ & 16.16 & $<0.675$ & 20.5 & 1657 & 0.0124 & & 15.9 & & \\
\hline $\mathrm{Yb}$ & 26.4 & 1672 & 0.0158 & & 20.4 & & 14.8 & 1587 & 0.0093 & $1.04^{\mathrm{c}}$ \\
\hline $\mathrm{Lu}$ & 26.9 & 1676 & 0.016 & $<1.92$ & 12.3 & $<0.156$ & 18.4 & 1479 & 0.0124 & $0.157^{\mathrm{c}}$ \\
\hline Hf & 83.9 & 18.18 & 4.61 & 7452 & 1401 & 5.32 & 76 & 15.3 & 4.98 & $2.5^{\mathrm{c}}$ \\
\hline $\mathrm{Ta}$ & 3.74 & $<0.15$ & $>24.9$ & 3.21 & $<0.082$ & $>39$ & 1.19 & $<0.045$ & $>8.03$ & $0.38^{\mathrm{c}}$ \\
\hline $\mathrm{Pb}$ & 25.1 & 1629 & 0.0154 & & & & & & & \\
\hline Th & & & & & & & $<0.92$ & 1.71 & $<0.54$ & $1.5^{\mathrm{c}}$ \\
\hline V & 20,685 & 167 & 124 & 1775 & 38.2 & 46.5 & 13678 & 116 & 118 & $79^{\mathrm{d}}$ \\
\hline $\mathrm{Mn}$ & & & & & & & $<99$ & 290 & $<0.34$ & $430^{c}$ \\
\hline
\end{tabular}

All abundances in ppm: $D$ values calculated before rounding and are shown in bold. Values listed only where multiple measurements available. Partition coefficients not listed where real values are obviously far below the detection limit. Partition coefficients are also maximum values.

${ }^{\mathrm{b}}$ Numbers indicate run pressure in kbar/temperature in ${ }^{\circ} \mathrm{C}$.

${ }^{\mathrm{c}}$ Whole-rock analysis by INAA (analyst, Bernhard Spettel, Max-Planck-Institut, Mainz).

${ }^{\mathrm{d}}$ Whole-rock analysis by XRF (analyst Phil Robinson, University of Tasmania).

ICP-MS facilitated the collection of partitioning data for a more comprehensive palette of trace elements than was previously available. These data complement recently acquired data for rutile/fluid pairs (Brenan and Watson, 1991; Brenan et al., 1994; 1995; Ayers et al., 1997; Adam et al., 1997; Stalder et al., 1998; Ayers, 1998), allowing assessment of the relative importance of melting and dehydration reactions.

\section{EXPERIMENTAL AND ANALYTICAL TECHNIQUES}

To produce minerals and melts representative of subduction zone processes, we have conducted melting experiments in the pressure range 1.8 -2.5 GPa on the Lalkaldarno tonalite from Victoria, Australia, previously used in experiments by Jenner et al. (1993). Experiments were conducted in a single-stage piston-cylinder apparatus at the University of Göttingen using Pt capsules with graphite inner linings, and $\mathrm{CaF}_{2}$ as the pressure medium. Small amounts of water were added in liquid form. Two experiments were run without oxygen buffers; tests with small amounts of oxygen buffers used as sensors indicate the intrinsic $f \mathrm{O}_{2}$ imposed by the $\mathrm{CaF}_{2}+\mathrm{BN}+\mathrm{C}$ assembly to be very reducing, close to that of iron-wüstite. One experiment was performed with an iron-wüstite buffer (Expt. 69, indicated by IW in Table 1); this, however, should be of no consequence for the detected incompatible elements. The iron-wüstite experiment contained two separate inner graphite capsules, one with the sample and the other containing the buffer mixture. To ensure the presence of rutiles large enough to analyze by laser-ICP-MS (LAM), the natural rock powder was doped with additional $\mathrm{TiO}_{2}$ to a total of $5 \mathrm{wt} . \%$, and fused to a homogeneous glass before its use in the high-pressure partitioning experiments.

In addition to $\mathrm{TiO}_{2}$, extra trace elements were added to the starting materials of each experiment as one of two sets of eight elements:
Doping mix 1 contained about 2000 ppm each of Y, Ba, La, Nd, Sm, Dy, Er, and Hf; and doping mix 2 about 2000 ppm each of V, Rb, Nb, $\mathrm{Eu}, \mathrm{Gd}, \mathrm{Yb}, \mathrm{Lu}$, and $\mathrm{Pb}$. As can be seen from the abundance data in Table 1, similar partition coefficients were generally obtained from both doped and undoped experiments (e.g., $\mathrm{Nb}$ and $\mathrm{Hf}$ in experiments 71 and 42), demonstrating a close approach to equilibrium, and showing Henry's law behavior even for the case of crystals with $2 \% \mathrm{Nb}$. Further experimental details and results for trace element partitioning between silicate minerals and melts from these experiments will be given elsewhere; here, we restrict our attention to rutile.

Major elements were analyzed by electron microprobe using standard operating conditions. Trace elements were analyzed by laser ablation microprobe-ICP-MS (LAM) on polished mounts following electron microprobe analysis, from which the $\mathrm{TiO}_{2}$ analyses were used as internal standards for the LAM analyses. LAM data were collected at the Memorial University of Newfoundland using a frequency-quadrupled Nd:YAG laser $(\lambda=266 \mathrm{~nm})$ coupled to a Fisons PQII + "S" ICP-MS. NIST 610 glass was used for external standardization and laser energy was throttled to $0.001-0.005 \mathrm{~mJ} / \mathrm{pulse}$ by a manually controlled half-wave plate for the ablation of small rutile crystals. Pulse energy for glass analysis was generally $\sim 0.02 \mathrm{~mJ}$. Further details of the technique are given by Jenner et al. (1993) and Longerich et al. (1996). The operating conditions used enabled analysis of ablation spots as small as $5.5 \mu \mathrm{m}$, so that trace element partitioning data for numerous trace elements could be collected for three experiments despite the small crystal sizes.

\section{RESULTS AND DISCUSSION}

\subsection{Rutile/melt Partitioning}

Partition coefficients for trace elements between rutile and melt from the tonalite experiments are given in Table 1 . The 


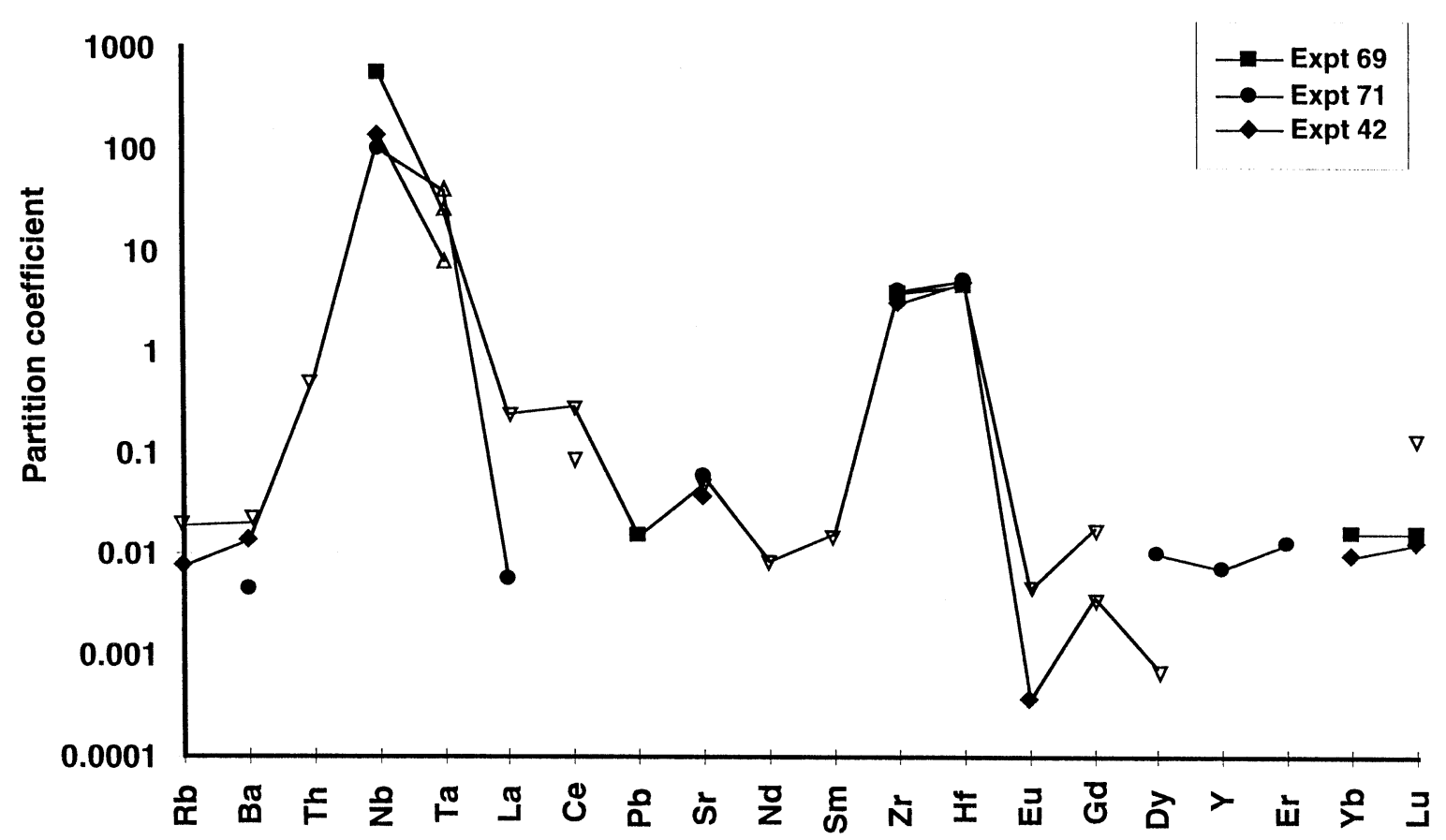

Fig. 1. Partition coefficients for trace elements between rutile and melt from experiments on the tonalite composition (from data given in Table 1). Solid symbols represent measured values; open triangles minimum (for Ta only) or maximum values - real values lie in direction pointed at by the symbol. The pattern shows a three-tier system of $D$ (Ru/melt) partitioning $D_{\mathrm{Nb} \text { Ta }}>D_{\mathrm{Zr}, \mathrm{Hf}}>D_{\text {others }}$, confirming the pattern found by Jenner et al. (1993) on the basis of much fewer elements.

overall pattern of partitioning is depicted in Figure 1, in which the element order follows that for upper mantle melting (Sun and McDonough, 1989). Downward-pointing open triangles indicate maximum values, meaning that the elements involved were analyzed in the glass but below the limit of detection (used in calculation of maximum $D_{\mathrm{Ru} / \mathrm{Lq}}$ ) in rutile. Values for Ta are minimum values, because Ta was not spiked in any experiment, and thus not detectable in the glasses. The pattern seen is a three-tier system, namely $\mathrm{Nb}$, Ta $>\mathrm{Zr}$, Hf $>$ all other trace elements analyzed, with approximate rutile/melt $D$ values of $>100, \sim 5$ and $\sim 0.01$, respectively. Although $D_{\mathrm{Ta}}$ could not be determined here, Jenner et al. (1993) observed $D_{\mathrm{Nb}} / D_{\mathrm{Ta}}$ $\sim 0.5$ for rutiles in the same tonalite composition.

The data are insufficient to delineate any pressure or temperature dependencies, although the higher $D_{\mathrm{Nb}}$ of 540 in the low temperature experiment 69 does appear logical as a temperature effect for a strongly compatible element in view of the tighter Onuma curves and higher optimal partition coefficient $D_{0}$ at lower temperatures. Maximization of $D_{0}$ at low temperatures is a consequence of higher resistance to deformation (higher Young's modulus), as also observed for garnets by Zack et al. (1997). The apparent negative Eu anomaly $\left(D_{\mathrm{Eu}}=\right.$ 0.0004 compared to the general level of $\sim 0.01$ in Figure 1 ) is probably real, but due to the reducing environment imposed by the experimental assembly; none of the other trace elements plotted are sensitive to the oxygen fugacity of the experiments.

In summary, the partitioning of "incompatible" trace elements between rutile and tonalitic melt defines three groups; $\mathrm{Nb}$, Ta $>\mathrm{Zr}$, Hf $>$ all others, whereby the $D$ values of the groups are separated by 1-2 and 2-3 orders of magnitude, respectively. The level for the third group at $D_{\mathrm{Ru} / \mathrm{Lq}} \sim 0.01$ is now established for 16 elements.

\subsection{Mineral/fluid Partitioning Experiments}

Following recent advances in experimental techniques (Ayers et al., 1992; Stalder et al., 1997), a number of experimental studies have presented partitioning data for trace elements between minerals and water-rich fluids, several of these supplying rutile/fluid partition coefficients (Ayers and Watson, 1993; Brenan et al., 1994; Ayers et al., 1997; Stalder et al., 1998; Ayers, 1998). The results for rutile/fluid are generally similar to those for rutile/melt presented here, with $D_{\mathrm{Nb}, \mathrm{Ta}}>$ $D_{\mathrm{Zr}, \mathrm{Hf}} \gg D_{\text {others }}$, although there appears to be less fractionation between $\mathrm{Nb}-\mathrm{Ta}$ and $\mathrm{Zr}-\mathrm{Hf}$ than in the case of rutile/melt partitioning (Fig. 1).

The ability of rutile to cause HFSE anomalies is illustrated in Figure 2 using data from Stalder et al. (1998) as this is the most complete data set delineating the anomalies. Figure 2 compares partition coefficients from experiments which were equivalent in pressure, temperature, and fluid composition, but differed in the investigated mineral assemblage: one consisted of only clinopyroxene, whereas the other was $90 \%$ clinopyroxene and $10 \%$ rutile, ensuring a broadly similar $\mathrm{SiO}_{2}$-rich major element chemistry of the fluid solute to that in the experiments using silicate minerals. The partitioning data for silicate mineral/fluid without rutile indicates that these are unlikely to cause HFSE anomalies. The indication found by Keppler (1996) that HFSE anomalies may result where fluids are rich in chlorine has not been reproduced in several studies at $P-T$ conditions more 


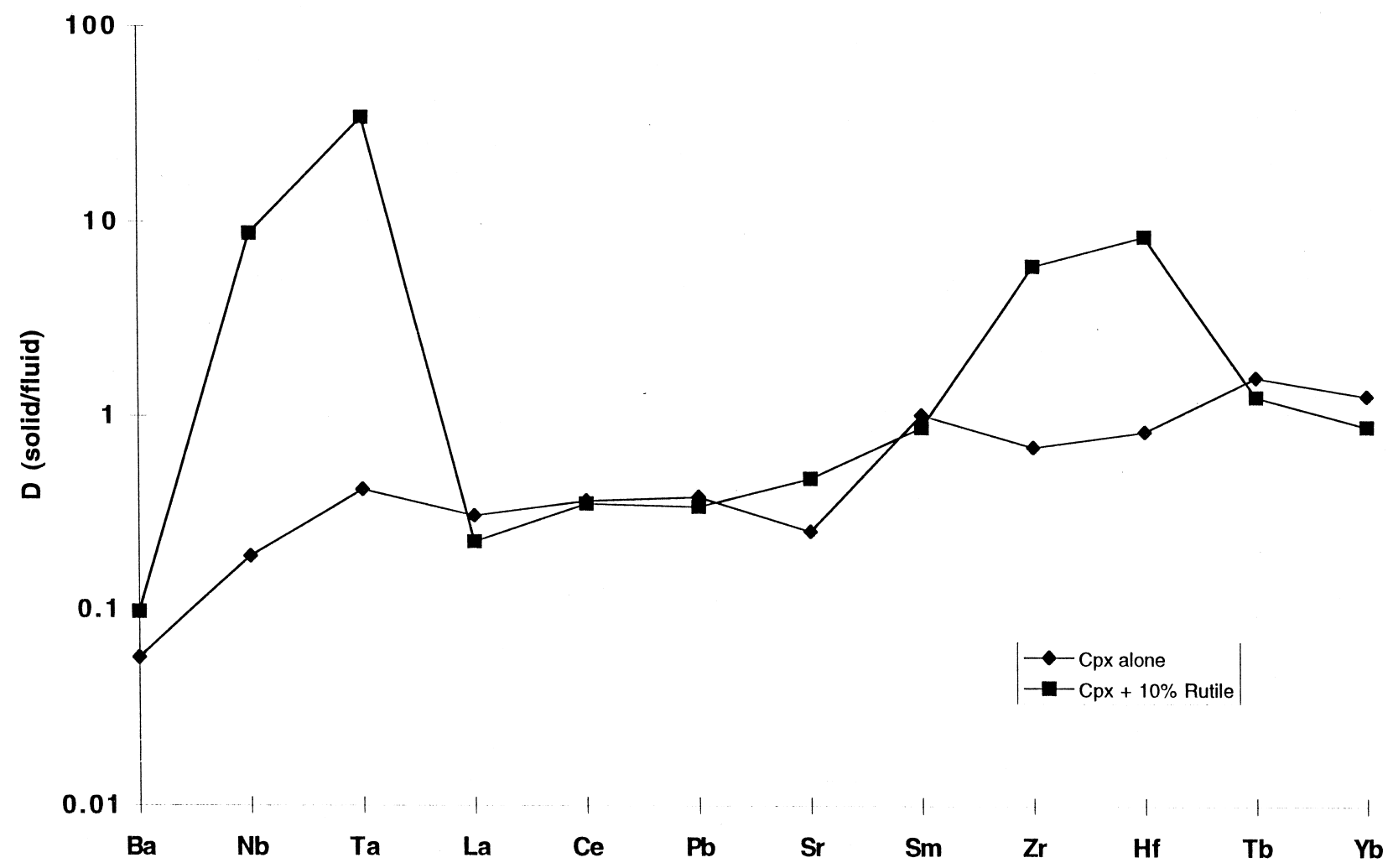

Fig. 2. Comparison of the partitioning pattern for cpx/fluid (filled diamonds) with that for ( $90 \% \mathrm{Cpx}+10 \%$ Rutile)/fluid at the same $P-T$ conditions of $5 \mathrm{GPa}$ and $1000^{\circ} \mathrm{C}$ (data from Stalder et al., 1998). The pattern for pure cpx shows no fractionation of the HFSE from other elements, as for garnet, indicating that loss of fluid from a bimineralic cpx $+\mathrm{Gt}$ assemblage cannot fractionate HFSE from other elements. The presence of $10 \%$ rutile causes an increase in $D$ (solid/fluid) by 1 to 2 orders of magnitude, so that loss of fluid from a rutile-bearing eclogite could fractionate these HFSE from other incompatible elements. This effect may be similar for much smaller proportions of rutile at lower temperatures, where higher $D_{\mathrm{Nb}}$ have been measured.

relevant to subduction processes (Ayers and Eggler, 1995; Brenan et al., 1995; Ayers et al., 1997; Adam et al., 1997; Stalder et al., 1998). The magnitude of the anomalies caused by rutile may be a strong function of temperature: Brenan et al. (1994) report $D$ values of 200-210 for $\mathrm{Nb}$, Ta (average values) and $\mathrm{Zr}$ in $\mathrm{H}_{2} \mathrm{O}$ fluids at $900^{\circ} \mathrm{C}$ and $2 \mathrm{GPa}$, whereas $D_{\mathrm{Nb}}$ and $D_{\mathrm{Ta}}$ are in the range of $50-70$ at $1000^{\circ} \mathrm{C}$ and both 2 and $5.7 \mathrm{GPa}$ (Brenan et al., 1994; Stalder et al., 1998). This appears to be consistent with the highest $D_{\mathrm{Nb}}$ in the lowest temperature experiment amongst the rutile/melt pairs in our present study. However, Ayers et al. (1997) and Ayers (1998) note no temperature effect and much higher $D_{\mathrm{Nb}}$ of 3000-3100 for rutile/ fluid in peridotitic systems.

In summary, fluid loss in subduction zones leaving an eclogite residue cannot cause fractionation of the HFSE from other trace elements without the presence of rutile in the residue. The fractionation of HFSE from other elements may be promoted at low temperatures characteristic of melting or dehydration of a subducting slab. A similar overall pattern of trace element partitioning is expected for rutile/fluid and rutile/melt pairs, but with a more pronounced partitioning of $\mathrm{Zr}$ and $\mathrm{Hf}$ into rutile coexisting with a fluid. The data now available contradict the generalization made by Green (1995) based on earlier experiments that $D_{\mathrm{Nb}} / D_{\mathrm{Ta}}>1$ for rutile/fluid, but $<1$ for rutile/melt.
Values for rutile/fluid show $D_{\mathrm{Nb}} / D_{\mathrm{Ta}}$ of approximately or slightly less than 1 (Brenan et al., 1994; Stalder et al., 1998).

\subsection{Implications for Subduction Zone Processes}

Subducted oceanic crust should consist principally of eclogite at depths if its melting point is reached in modern subduction zones, whereas melting of amphibolite may be more relevant to the Earth's early history. Experiments have shown eclogite, which may contain minor amounts of quartz and rutile, to produce melts similar in composition to tonalitic and quartz dioritic rocks (Arth and Hanson, 1972; Rapp and Watson, 1995). Dehydration melting of amphibolite also produces melts with high $\mathrm{SiO}_{2}$ contents (>60 wt.\%; Rapp et al., 1991; Wolf and Wyllie, 1994) and thus with low $\mathrm{TiO}_{2}$ saturation levels (Green and Pearson, 1986; Ryerson and Watson, 1987). Thus, the stability of rutile at the initiation of partial melting is to be expected. The previous subduction history of the oceanic crustal slab should not affect this conclusion. Although dehydration reactions in the subducting slab at lower pressures may result in loss of about $70 \%$ of the initial water content according to Poli and Schmidt (1995), the solubility of $\mathrm{TiO}_{2}$ in fluids at low temperatures corresponding to these dehydration reactions is extremely limited (Ayers and Watson, 
1993) so that essentially no loss of $\mathrm{TiO}_{2}$ occurs during this process.

The large palette of trace elements presented here for rutile/ melt pairs allows improved definition of the fractionated trace element patterns which rutile should cause. Rutile coexisting with a melt exhibits a three-tier pattern of trace elements $(\mathrm{Nb}$, $\mathrm{Ta}>\mathrm{Zr}$, Hf $>$ others), which should result in strong negative anomalies for $\mathrm{Nb}$ and $\mathrm{Ta}\left(D_{\mathrm{Ru} / \mathrm{Lq}} \sim 100-500\right)$, and smaller but noticeable negative anomalies for $\mathrm{Zr}$ and $\mathrm{Hf}$ since these are still compatible elements in rutile $\left(D_{\mathrm{Ru} / \mathrm{Lq}} \sim 5\right.$; Table 1$)$. In many island arc magmas, the $\mathrm{Zr}$ and $\mathrm{Hf}$ anomalies are less marked relative to those for $\mathrm{Ti}$, and especially those for $\mathrm{Nb}$ and $\mathrm{Ta}$ (Briqueau et al., 1984). $D_{\mathrm{Ru} / \mathrm{Lq}}$ for titanium is another expression for the solubility of $\mathrm{TiO}_{2}$ in the melt, and should be $80-90$ for $\mathrm{SiO}_{2}$-rich melts from subducted crust. Thus, the $D_{\mathrm{HFSE}}$ signature of rutile/melt pairs in the tonalitic system is remarkably similar to the signature of many island arc magmas.

According to the experimental studies cited above, dehydration of former ocean crust would exhibit a similar pattern, but with more marked negative anomalies for $\mathrm{Zr}$ and $\mathrm{Hf}$ in the fluid than in the case of melting. The presence of rutile appears to be essential, as silicate minerals alone do not fractionate HFSE from other trace elements sufficiently to cause HFSE anomalies (Ayers and Eggler, 1995; Brenan et al., 1995; Ayers et al., 1997; Adam et al., 1997; Stalder et al., 1998). Thus, either fluids or melts in equilibrium with rutile in the subducting slab have the potential to cause the trace element pattern characteristic of island arc basalts. However, thermal gradients in subducting slabs in the modern Earth are mostly not hot enough to allow melting (Peacock, 1996), so that a role for fluids should be considered more likely.

The finding that $\mathrm{Zr}$ and $\mathrm{Hf}$ are preferentially accommodated in rutile with respect to melts and fluids under all relevant conditions appears to contradict a role for rutile in the production of the geochemical signature of the continental crust (see Tables 8 and 9 in Rudnick and Fountain, 1995; noting that Figure 12 in this paper is incorrectly plotted). However, our results on the Lalkaldarno tonalite also show that $D_{\mathrm{Zr}} / D_{\mathrm{Sm}}$ for $\mathrm{cpx} / \mathrm{melt}$ are much lower $(0.20)$ than previously measured in experiments on basaltic systems (average 0.45 ), so that positive $\mathrm{Zr} / \mathrm{Sm}$ in the melt may occur because of the high modal abundance of cpx outweighing the opposite effect of rutile during melting of rutile-bearing eclogite.

Although the similarity between the rutile partitioning pattern and that of island arc magmas appears too good to be fortuitous, two caveats remain. Firstly, the $\mathrm{Nb} / \mathrm{Ta}$ ratio of the continental crust of 10-14 (Rudnick and Fountain, 1995; Plank and Langmiur, 1998) is substantially lower than the primitive mantle value of 17 (Sun and McDonough, 1989). Recent data indicate that values both considerably higher and lower than 17 are found in various types of island arc magmas (Stolz et al., 1996; Eggins et al., 1997), with lower values being found amongst potassium-poor tholeiites (S. M. Eggins, private communication). The production of low $\mathrm{Nb} / \mathrm{Ta}$ in the mantle wedge implies high $\mathrm{Nb} / \mathrm{Ta}$ in the complementary residuum (McDonough, 1991), which appears not to apply for either rutile/melt or rutile/fluid pairs. Rutile/fluid fractionation has been suggested as the likely cause of low $\mathrm{Nb} / \mathrm{Ta}$ in fluids (Green, 1995), but this has not been confirmed by more recent results. A possible solution to this problem is offered by Linnen and Keppler
(1997), who calculate that rutile/melt $D_{\mathrm{Nb}} / D_{\mathrm{Ta}}$ should be appreciably greater than 1 in non-alkaline granitic systems. However, there is no experimental confirmation to date that $D_{\mathrm{Nb}}>$ $D_{\mathrm{Ta}}$ for rutile/melt pairs in melt compositions relevant to slab melting (Jenner et al., 1993).

A recently acquired extensive data set of experimental amphibole/melt partitioning and crystal structure refinements shows complex behavior of the HFSE, including conditions in which $D_{\mathrm{Nb}}>D_{\mathrm{Ta}}$ (Tiepolo et al., 1999). This may have the potential to explain HFSE fractionation without titanate phases by the action of amphibole in either the melting slab or in the mantle wedge. More simultaneous analyses of $\mathrm{Nb}$ and $\mathrm{Ta}$ in various conditions for various minerals will be required before $\mathrm{Nb} / \mathrm{Ta}$ is adequately accounted for. For example, many ilmenites occurring as megacrysts in kimberlite or in mantle xenoliths appear to have $\mathrm{Nb} / \mathrm{Ta}$ lower than 17 , and as low as 8-10 (Mitchell et al., 1973; Zack and Brumm, 1998), whereas ilmenites in mantle rocks with $\mathrm{Nb} / \mathrm{Ta}=21$ are known (Foley et al., 1995).

The second caveat addresses the assumption that rutile in subducting eclogitic ocean crust is the most likely titanate in the source regions of island arc magmas. Whereas high $\mathrm{TiO}_{2}$ solubility in basaltic melts eliminates the possibility of titanate minerals as equilibrium phases in mantle peridotite, the possibility remains that they are present in pyroxene-rich veins in the mantle which originate by the influx of melts or fluids and their reaction with peridotite (Foley and Wheller, 1990; Ringwood, 1990). Titanate minerals may be stable in these circumstances.

Acknowledgements-Funding by Deutsche Forschungsgemeinschaft grant Fo $181 / 2-3$ to S.F.F. is gratefully acknowledged. We thank S. M. Eggins, A. J. Crawford, P. Robinson, and B. Spettel for providing materials (geological or electronic) or analyses, and I. Horn for assistance during acquisition of LAM-ICP-MS data. Comments on this paper from J. Ayers and S. R. van der Laan, three anonymous reviewers, and the Harvard geochemistry group are much appreciated.

\section{REFERENCES}

Adam J., Green T. H., Sie S. H., and Ryan C. G. (1997) Trace element partitioning between aqueous fluids, silicate melts and minerals. Eur. J. Mineral. 9, 569-584.

Arth J. and Hanson G. N. (1972) Quartz diorites derived by partial melting of eclogite or amphibolite at mantle depths. Contrib. Mineral. Petrol. 37, 161-174.

Ayers J. C. (1998) Trace element modeling of aqueous fluid-peridotite interaction in the mantle wedge of subduction zones. Contrib. Mineral. Petrol. 132, 390-404.

Ayers J. C. and Eggler D. H. (1995) Partitioning of elements between silicate melt and $\mathrm{H}_{2} \mathrm{O}-\mathrm{NaCl}$ fluids at 1.5 and $2.0 \mathrm{GPa}$ pressure: Implications for mantle metasomatism. Geochim. Cosmochim. Acta 59, 4237-4246.

Ayers J. C. and Watson E. B. (1993) Rutile solubility and mobility in supercritical aqueous fluids. Contrib. Mineral. Petrol. 114, 321-330.

Ayers J. C., Brenan J. M., Watson E. B., Wark D. A., and Minarik W. G. (1992) A new capsule technique for hydrothermal experiments using the piston-cylinder apparatus. Am. Mineral. 77, 1080-1086.

Ayers J. C., Dittmer S. K., and Layne G. D. (1997) Partitioning of elements between peridotite and $\mathrm{H}_{2} \mathrm{O}$ at 2.0-3.0 GPa and 900$1100^{\circ} \mathrm{C}$ and application to models of subduction zone processes. Earth Planet. Sci. Lett. 150, 381-398.

Brenan J. M. and Watson E. B. (1991) Partitioning of trace elements between olivine and aqueous fluids at high $P-T$ conditions: Implications for the effect of fluid composition on trace-element transport. Earth Planet. Sci. Lett. 107, 672-688.

Brenan J. M., Shaw H. F., Phinney D. L., and Ryerson F. J. (1994) 
Rutile-aqueous fluid partitioning of $\mathrm{Nb}, \mathrm{Ta}, \mathrm{Hf}, \mathrm{Zr}, \mathrm{U}$ and $\mathrm{Th}$ : Implications for high field strength element depletions in island-arc basalts. Earth Planet. Sci. Lett. 128, 327-339.

Brenan J. M., Shaw H. F., Ryerson F. J., and Phinney D. L. (1995) Mineral-aqueous fluid partitioning of trace elements at $900^{\circ} \mathrm{C}$ and $2.0 \mathrm{GPa}$ : Constraints on the trace element chemistry of mantle and deep crustal fluids. Geochim. Cosmochim. Acta 59, 3331-3350.

Briqueau L., Bougault H., and Joron J.-L. (1984) Quantification of Nb, $\mathrm{Ta}, \mathrm{Ti}$ and $\mathrm{V}$ anomalies in magmas associated with subduction zones: petrogenetic implications. Earth Planet. Sci. Lett. 68, 297208.

Eggins S. M., Woodhead J. D., Kinsley L. P. J., Mortimer G. E., Sylvester P., McCulloch M. T., Hergt J. M., and Handler M. R. (1997) A simple method for the precise determination of $=40$ trace elements in geological samples by ICP-MS using enriched isotope internal standardisation. Chem. Geol. 134, 311-326.

Foley S. F. and Wheller G. E. (1990) Parallels in the origin of the geochemical signatures of island arc volcanics and continental potassic igneous rocks: The role of residual titanates. Chem. Geol. 85, $1-18$.

Foley S. F., Jenner G. A., Konzett J., and Sweeney R. J. (1995) Trace element partitioning in natural phlogopite- and K-richterite-bearing xenoliths from southern African kimberlites. Sixth International Kimberlite Conference, Novosibirsk, pp. 164-166. Siberian Branch, Russian Academy of Sciences.

Green T. H. (1995) Significance of Nb/Ta as an indicator of geochemical processes in the crust-mantle system. Chem. Geol. 120, 347-359.

Green T. H. and Pearson N. J. (1986) Ti-rich accessory phase saturation in hydrous mafic-felsic compositions at high P, T. Chem. Geol. 54, 185-201.

Jenner G. A., Foley S. F., Jackson S. E., Green T. H., Fryer B. J., Longerich H. P. (1993) Determination of partition coefficients for trace elements in high pressure-temperature experimental run products by laser ablation microprobe-inductively coupled plasma-mass spectrometry (LAM-ICP-MS). Geochim. Cosmochim. Acta 57, 5099-5103.

Keppler, H. (1996) Constraints from partitioning experiments on the composition of subduction zone fluids. Nature 380, 237-240.

Linnen R. L. and Keppler H. (1997) Columbite solubility in granitic melts: Consequences for the enrichment and fractionation of $\mathrm{Nb}$ and Ta in the Earth's crust. Contrib. Mineral. Petrol. 128, 213-237.

Longerich H. P., Jackson S. E., and Günther D. (1996) Laser ablation inductively coupled plasma mass spectrometric transient signal data acquisition and analyte concentration calculation. J. Anal. Atom. Spectr. 11, 899-904.

McDonough W. F. (1991) Partial melting of subducted oceanic crust and isolation of its residual eclogitic lithology. Phil. Trans. Roy. Soc. London A 335, 407-418.

McLennan S. M. and Taylor S. R. (1982) Geochemical constraints on the growth of the continental crust. J. Geol. 90, 347-361.

Mitchell R. H., Brunfelt A. O., and Nixon P. H. (1973) Trace elements in magnesian ilmenites from Lesotho kimberlites. In Lesotho Kimberlites (ed. P. H. Nixon), pp. 230-237. Lesotho National Development Corp., Maseru, Lesotho.

Nelson B. K. and DePaolo D. J. (1985) Rapid production of continental crust 1.7 to 1.9 by ago: $\mathrm{Nd}$ isotopic evidence from the basement of the North American mid-continent. Geol. Soc. Amer. Bull. 96, 746754.

Peacock S. M. (1996) Thermal and petrologic structure of subduction zones. In Subduction: Top to Bottom (ed. G. E. Bebout, D. W. Scholl, S. H. Kirby, and J. P. Platt), pp. 119-133. AGU, Washington.
Plank T. and Langmuir C. H. (1998) The chemical composition of subducting sediment and its consequences for the crust and mantle. Chem. Geol. 145, 325-394.

Poli S. and Schmidt M. W. (1995) $\mathrm{H}_{2} \mathrm{O}$ transport and release in subduction zones: Experimental constraints on basaltic and andesitic systems. J. Geophys. Res. 100, 22299-22314.

Rapp R. P. and Watson E. B. (1995) Dehydration melting of metabasalt at 8-32 kbar implications for continental growth and crust-mantle recycling. J. Petrol. 36, 891-931.

Rapp R. P., Watson E. B., and Miller C. F. (1991) Partial melting of amphibolite/eclogite and the origin of Archean trondhjemites and tonalites. Precamb. Res. 51, 1-25.

Ringwood A. E. (1990) Slab-mantle interactions. 3. Petrogenesis of intraplate magmas and structure of the upper mantle. Chem. Geol. 82, 187-207.

Rudnick R. L. and Fountain D. M. (1995) Nature and composition of the continental crust: A lower crustal perspective. Rev. Geophys. 33, 267-209.

Ryerson F. J. and Watson E. B. (1987) Rutile saturation in magmas: Implications for $\mathrm{Ti}-\mathrm{Nb}-\mathrm{Ta}$ depletion in island-arc basalts. Earth Planet. Sci. Lett. 86, 225-239.

Stalder R., Foley S. F., Brey G. P., Forsythe L. M., and Horn I. (1997) First results from a new experimental technique to determine fluid/ solid trace element partition coefficients using diamond aggregate extraction traps. N. Jb. Miner. Abh. 172, 117-132.

Stalder R., Foley S. F., Brey G. P., and Horn I. (1998) Mineral-aqueous fluid partitioning of trace elements at $900-1200^{\circ} \mathrm{C}$ and $3.0-5.7 \mathrm{GPa}$ : New experimental data for garnet, clinopyroxene, and rutile, and implications for mantle metasomatism. Geochim. Cosmochim. Acta 62, 1781-1801.

Stolz A. J., Jochum K.-P., Spettel B., and Hofmann A. W. (1996) Fluid and melt related enrichment in the subarc mantle: Evidence from $\mathrm{Nb} / \mathrm{Ta}$ variations in island arc basalts. Geology 24, 587-590.

Sun S.-S. and McDonough W. F., 1989. Chemical and isotopic systematics of oceanic basalts: Implications for mantle composition and processes. In Magmatism in the Ocean Basins (ed. A. D. Saunders and M. J. Norry), pp. 313-345. Geol. Soc. Spec. Publ. 42.

Taylor S. R. and McLennan S. M. (1985) The Continental Crust: Its Composition and Evolution. Blackwell.

Thirlwall M. F., Smith T. E., Graham A. M., Theodorou N., Hollings P., Davidson J. P., and Arculus R. J. (1994) High field strength element anomalies in arc lavas: source or process? J. Petrol. 35, $819-838$.

Tiepolo M., Oberti R., Vannucci R., and Zanetti A. (1999) ${ }^{A m p h / L} D$ für $\mathrm{Nb}$ and Ta: Crystal-chemical control and implications for subduction-related magmatism. Geophys. Res. Abstr. EGS XXIV, The Hague, p. 36 (abstr.).

Woodhead J., Eggins S., and Gamble J. (1993) High field strength and transition element systematics in island arc and back-arc basin basalts: Evidence for multi-phase extraction and a depleted mantle wedge. Earth Planet. Sci. Lett. 114, 491-504.

Wolf M. B. and Wyllie P. J. (1994) Dehydration melting of amphibolite at $10 \mathrm{kbar}$ : The effects of temperature and time. Contrib. Mineral. Petrol. 115, 369-383.

Zack T. and Brumm R. (1998) Ilmenite/liquid partition coefficients of 26 trace elements determined through ilmenite/clinopyroxene partitioning in garnet pyroxenites. Seventh International Kimberlite Conference, Cape Town, pp. 986-988.

Zack T., Foley S. F., and Jenner G. A. (1997) A consistent partition coefficient set for clinopyroxene, amphibole and garnet from laser ablation microprobe analysis of garnet pyroxenites from Kakanui, New Zealand. N. Jb. Miner. Abh. 172, 23-41. 